\title{
Intercellular pathway of leucine catabolism in rat spermatogenic epithelium
}

\author{
J. Anton GROOTEGOED, Ruud JANSEN and Henk J. VAN DER MOLEN \\ Department of Biochemistry (Division of Chemical Endocrinology), Medical Faculty, Erasmus University \\ Rotterdam, P.O. Box 1738, 3000 DR Rotterdam, The Netherlands
}

(Received 30 November 1984/23 January 1985; accepted 28 January 1985)

\begin{abstract}
A unique intercellular pathway of leucine catabolism was observed in vitro in rat spermatogenic epithelium. Sertoli cells convert leucine via transmination into 4methyl-2-oxovalerate, and spermatocytes and spermatids reduce exogenous 4-methyl2-oxovalerate to 2-hydroxy-4-methylvalerate, which is then released by the spermatogenic cells. The NADH-dependent reduction of 4-methyl-2-oxovalerate could be catalysed by the male-germ-cell-specific lactate dehydrogenase isoenzyme LDH-C 4 in the cytosol of the spermatogenic cells, concomitant with the NAD ${ }^{+}$dependent conversion of exogenous lactate into pyruvate.
\end{abstract}

In the testicular tubules of mammals, Sertoli cells support the spermatogenic cells. Spermatogenesis is dependent on testosterone and follitropin, and there is evidence that Sertoli cells, but not spermatocytes and spermatids, are hormone target cells (Fritz, 1978). The support of spermatogenic cells by Sertoli cells might include the cell-tocell transport of intermediates of metabolism. This notion is substantiated by the observation that isolated rat spermatocytes and spermatids require a high concentration of exogenous lactate for ATP production (Jutte et al., 1981; Grootegoed et al., 1984), whereas Sertoli cells produce lactate from glucose at a very high rate (Jutte et al., 1981; Robinson \& Fritz, 1981). There was no direct evidence, however, that in the spermatogenic epithelium compounds from Sertoli cells are utilized by germ cells. We now have obtained such evidence for the metabolism of leucine. Fragments of rat spermatogenic epithelium, which contain Sertoli cells plus spermatogenic cells, can produce 2-hydroxy-4-methylvalerate from leucine. It appers that Sertoli cells convert leucine via transamination into 4-methyl-2-oxovalerate, whereas spermatocytes and spermatids reduce exogenous 4-methyl-2-oxovalerate to 2-hydroxy-4-methylvalerate.

\section{Experimental}

Isolation and incubation of cells

Sertoli cells and fragments of spermatogenic epithelium were isolated by collagenase treatment of decapsulated testes from immature Wistar rats, as described by Jutte et al. (1982). Sertoli cells were isolated from rats that had been irradiated in utero at day 19 of gestation (Beaumont, 1960). The testes of these irradiated rats do not contain developing germ cells. Fragments of spermatogenic epithelium, containing Sertoli cells plus spermatogenic cells, were isolated from testes of non-irradiated rats. The presence of a large number of pachitene spermatocytes and round spermatids in these isolated fragments was observed by flow-cytometric analysis of the number of cells with a $4 \mathrm{C}$ amount or a $1 \mathrm{C}$ amount of DNA ( $1 \mathrm{C}$ is the amount of DNA in a haploid cell) (Jutte et al., 1982). For the isolation of pachytene spermatocytes and round spermatids, the spermatogenic epithelium was treated with trypsin to obtain a cell suspension, and subsequently the different cell types were separated by sedimentation at unit gravity, as described by Grootegoed et al. $(1982,1984)$.

Sertoli cells and spermatogenic epithelium were incubated in Eagle's minimum essential medium (Eagle, 1959), supplemented with penicillin $\left(10^{5}\right.$ units $\left./ 1\right)$, streptomycin $(100 \mathrm{mg} / \mathrm{l})$, fungizone $(1 \mathrm{mg} / \mathrm{l})$, non-essential amino acids and L-leucine (final concn. $2 \mathrm{mM}$ ). Spermatocytes and spermatids were also incubated in this medium, with the following extra additions : $0.4 \%(\mathrm{w} / \mathrm{v})$ bovine serum albumin (fraction V), 0.25 mM-sodium 4-methyl2-oxovalerate, and either $2 \mathrm{~mm}$-sodium pyruvate or $6 \mathrm{~mm}$-sodium L-lactate. All incubations were carried out at $32^{\circ} \mathrm{C}$ under an atmosphere of $5 \%$ $\mathrm{CO}_{2}$ in air. After $20 \mathrm{~h}$ of incubation, the organic acids present in the spent incubation medium were analysed by g.l.c. 


\section{G.l.c.}

$\mathrm{NaOH}(0.5 \mathrm{ml} ; 5 \mathrm{M})$ and hydroxylamine hydrochloride $(0.5 \mathrm{ml} ; 10 \%, \mathrm{w} / \mathrm{v})$ were added to $2 \mathrm{ml}$ of spent incubation medium. Fumaric acid ( 50 or $100 \mathrm{nmol}$ ) was added as an internal standard. This mixture was incubated for $30 \mathrm{~min}$ at $60^{\circ} \mathrm{C}$, followed by addition of $\mathrm{HCl}(0.8 \mathrm{ml} ; 12 \mathrm{M})$. The sample was extracted with three $3 \mathrm{ml}$ portions of ethyl acetate. The ethyl acetate was evaporated $\left(\right.$ at $50^{\circ} \mathrm{C}$, under a stream of $\mathrm{N}_{2}$ ), the residue was dissolved in $50 \mu \mathrm{l}$ of Tri-Sil-BSA Formula P (Pierce Chemical Co., Rockford, IL, U.S.A.), and the sample was incubated for $30 \mathrm{~min}$ at $60^{\circ} \mathrm{C}$. A sample $(2 \mu \mathrm{l})$ of the final preparation was injected on to a $10 \%$ OV-17 column (Gaschrom Q support, 80-100 mesh; Chrompack, Middelburg, The Netherlands) with a length of $180 \mathrm{~cm}$ and an internal diameter of $3 \mathrm{~mm}$, in a gas-liquid chromatograph (Hewlett-Packard model 402). $\mathrm{N}_{2}$ was the carrier gas, at a flow rate of $60 \mathrm{ml} / \mathrm{min}$. Oven temperature was programmed from 100 to $190^{\circ} \mathrm{C}$ at a rate of $5^{\circ} \mathrm{C} / \mathrm{min}$, with an initial delay of $6 \mathrm{~min}$ at $100^{\circ} \mathrm{C}$. The retention times and peak areas of the different compounds were determined automatically (Hewlett-Packard 3370 B integrator). The peak areas obtained after extraction of medium containing equimolar amounts of 4-methyl-2-oxovalerate, 2-hydroxy-4methylvalerate and fumaric acid, relative to that of the internal standard fumaric acid (peak area 1.0 ), were $1.1 \pm 0.04$ and $0.9 \pm 0.2$ respectively (means \pm S.D., $n=6$ ). The different peaks were identified by using reference compounds and hydrocarbon standards $\left(\mathrm{C}_{10}, \mathrm{C}_{12}, \mathrm{C}_{14}\right.$ and $\left.\mathrm{C}_{16}\right)$, as described by Tanaka et al. (1980). The amount of cellular protein was measured by the method of Lowry et al. (1951), with bovine serum albumin as standard.

\section{Results and discussion}

Sertoli cells, but not spermatocytes and spermatids, contain a high activity of branched-chain amino acid aminotransferase (L-leucine: 2-oxoglutarate aminotransferase, EC 2.6.1.6) (Grootegoed et al., 1983). Via this enzyme activity, the branched-chain amino acids (leucine, isoleucine and valine) can be converted into the corresponding branched-chain $\alpha$-oxo acids. In different tissues, branched-chain $\alpha$-oxo acids are either decarboxylated via the branched-chain $\alpha$-oxo acid dehydrogenase complex or released by cells (Shinnick \& Harper, 1976). The present results show net production of 4-methyl-2-oxovalerate from leucine by rat Sertoli cells in vitro. This branched-chain $\alpha$-oxo acid was released by the Sertoli cells (Fig. 1 and Table 1). There was no detectable production of 4-methyl-2-oxovalerate

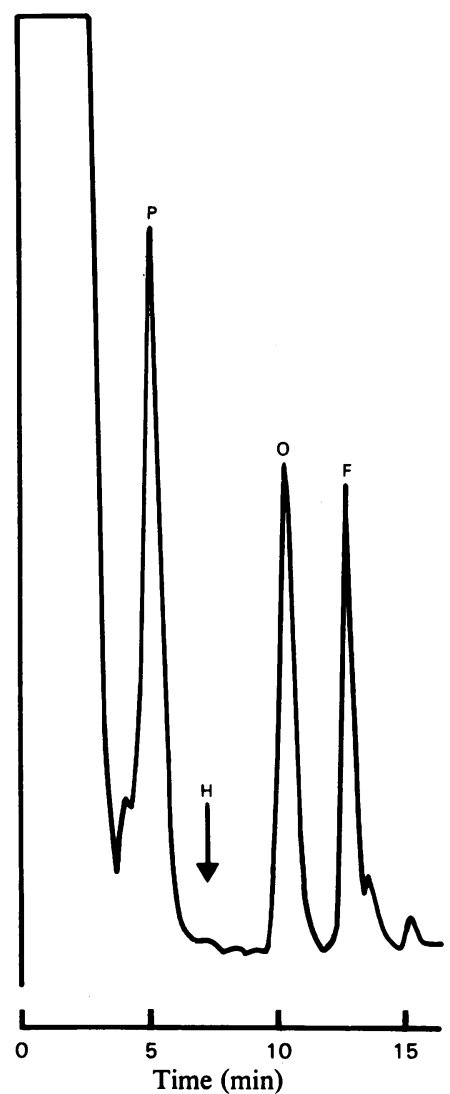

Fig. 1. Release of 4-methyl-2-oxovalerate by Sertoli cells The Sertoli cells were isolated from 3-week-old sterile rats and incubated for $20 \mathrm{~h}$ in Eagle's minimum essential medium containing $2 \mathrm{mM}-\mathrm{L}-$ leucine. The spent incubation medium was analysed by g.l.c. The peak marked $P$ represents net production of pyruvate by Sertoli cells (Jutte et al., 1983). The positions of 2-hydroxy-4-methylvaleric acid (H), 4-methyl-2-oxovaleric acid $(\mathrm{O})$ and fumaric acid $(F)$ are indicated.

by Sertoli cells during incubation in the absence of exogenous leucine, and by isolated spermatocytes and spermatids during incubation in the presence of $2 \mathrm{~mm}$-L-leucine (results not shown).

Spermatocytes and spermatids from mammalian species contain a lactate dehydrogenase isoenzyme that is composed of male-germ-cellspecific C subunits (LDH-C ${ }_{4}$ or LDH-X) (Meistrich et al., 1977; Chang et al., 1980). Isoenzyme $\mathrm{LDH}-\mathrm{C}_{4}$ from mouse testis has a broad substrate specficity, and catalyses the NAD-dependent interconversion of branched-chain $\alpha$-oxo acids and branched-chain $\alpha$-hydroxy acids as well as the interconversion of pyruvate and lactate (Blanco et al., 1976). 
Table 1. Rates of net production of 4-methyl-2-oxovalerate and 2-hydroxy-4-methylvalerate by Sertoli cells and spermatogenic epithelium

Sertoli cells and spermatogenic epithelium were isolated from 3-week-old sterile or intact rats respectively, and incubated for $20 \mathrm{~h}$ in Eagle's minimum essential medium containing $2 \mathrm{~mm}-\mathrm{L}$-leucine. The quantitative data were obtained by g.l.c. and represent the means \pm S.D. for quadruplicate incubations. The limit of detection was approx. $10 \mathrm{nmol} / 20 \mathrm{~h}$ per $\mathrm{mg}$ of protein.

Production rate (nmol/20h per $\mathrm{mg}$ of protein)

Sertoli cells

Spermatogenic epithelium

$\begin{array}{cc}205 \pm 22 & \text { Not detected } \\ 26 \pm 5 & 124 \pm 17\end{array}$

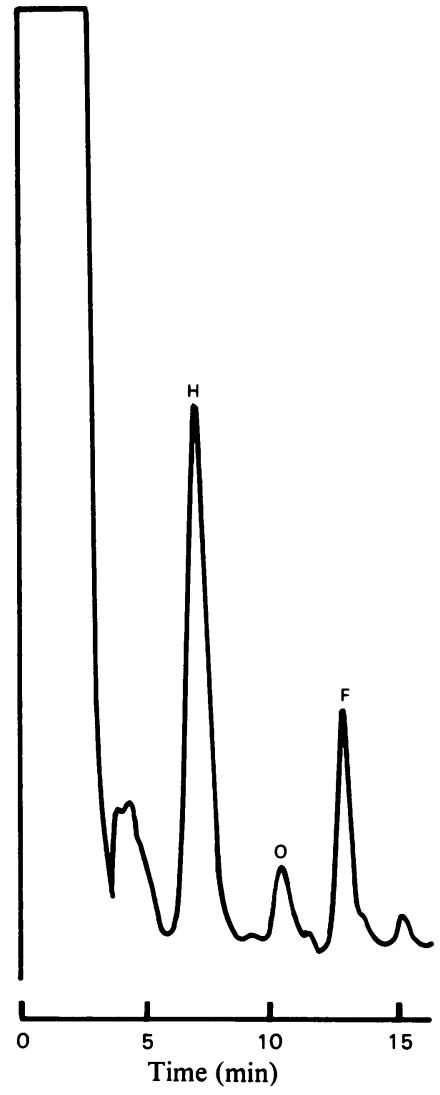

Fig. 2. Reduction of exogenous 4-methyl-2-oxovalerate by isolated pachytene spermatocytes

The isolated spermatocytes were incubated for $20 \mathrm{~h}$ in Eagle's minimum essential medium containing $0.25 \mathrm{~mm}$-sodium 4-methyl-2-oxovalerate and $6 \mathrm{~mm}$ sodium L-lactate. The spent incubation medium was. analysed by g.l.c. The positions of 2-hydroxy-4methylvaleric acid $(\mathrm{H})$, 4-methyl-2-oxovaleric acid (O) and fumaric acid (F) are indicated.

In the present experiments, it was found that exogenous 4-methyl-2-oxovalerate was reduced to 2-hydroxy-4-methylvalerate by isolated rat pachytene spermatocytes (Fig. 2). The glucose-con- taining incubation medium was supplemented with sodium L-lactate $(6 \mathrm{mM})$. ATP production by isolated spermatogenic cells can also be supported by exogenous pyruvate (Grootegoed et al., 1984). Formation of 2-hydroxy-4-methylvalerate from exogenous 4-methyl-2-oxovalerate, however, did not occur during incubation of the spermatocytes in the presence of pyruvate (results not shown). This can be explained, because exogenous pyruvate is converted into lactate at a high rate (Grootegoed et al., 1984), which may result in a highly oxidized NADH/NAD ${ }^{+}$system (Brooks \& Mann, 1972).

The same results were obtained with round spermatids. The rate of production of 2-hydroxy-4methylvalerate by spermatids (estimated after $4 \mathrm{~h}$ of incubation, when less than $50 \%$ of the exogenous 4-methyl-2-oxovalerate had been reduced) was $3.8 \pm 0.3 \mathrm{nmol} / \mathrm{h}$ per $10^{6}$ cells. The rate of lactate oxidation during this incubation period, estimated as described previously (Grootegoed et al., 1984) from the rate of conversion of $\mathrm{L}-\left[\mathrm{U}-{ }^{14} \mathrm{C}\right]$ lactate into ${ }^{14} \mathrm{CO}_{2}$, was $3.8 \pm 0.2 \mathrm{nmol} / \mathrm{h}$ per $10^{6}$ cells (means \pm S.D. for triplicate incubations). Hence it appears that the rate of 4-methyl-2-oxovalerate reduction is comparable with the rate of lactate oxidation.

Fragments of spermatogenic epithelium (which contain Sertoli cells plus spermatogenic cells) were incubated in the presence of glucose and leucine, but in the absence of added lactate and 4-methyl-2oxovalerate. The results (Table 1) indicate that, in the epithelial fragments, 4-methyl-2-oxovalerate was produced from leucine by Sertoli cells and then reduced to 2-hydroxy-4-methylvalerate by the spermatogenic cells. Moreover, it appears from the present results that the germ cells in the spermatogenic microenvironment may be exposed to a relatively high concentration of lactate, so that the germ cells can convert exogenous lactate into pyruvate and produce ATP via mitochondrial oxidation of the endogenous pyruvate. In the spermatogenic cells, cytosolic NADH could be oxidized via the reduction of exogenous 4-methyl2-oxovalerate to 2-hydroxy-4-methylvalerate, con- 
comitant with the $\mathrm{NAD}^{+}$-dependent conversion of exogenous lactate into pyruvate.

The present results provide evidence that spermatogenic cells in situ in the spermatogenic epithelium can utilize metabolic intermediates (lactate and 4-methyl-2-oxovalerate) that are produced by Sertoli cells (from glucose and leucine respectively). The production of 2-hydroxy-4-methylvalerate from leucine by the spermatogenic epithelium represents a unique intercellular pathway of leucine catabolism. It is not certain, however, that the reduction of branched-chain $\alpha$-oxo acids by the spermatogenic cells is of physiological importance. This reduction could reflect the coincidence that (1) Sertoli cells release branchedchain $\alpha$-oxo acids, that (2) male germ cells contain a lactate dehydrogenase isoenzyme with a broad substrate specificity, and that (3) the NADH/ $\mathrm{NAD}^{+}$ratio in the cytosol of germ cells in situ is sufficiently high to cause reduction of the exogenous $\alpha$-oxo acids. A high NADH/NAD ${ }^{+}$ratio in the cytosol of the spermatogenic cells could result from the conversion of exogenous lactate into pyruvate. It has been shown that NADH accumulates in ram and boar spermatozoa during incubation in the presence of lactate (Brooks \& Mann, 1972). This may indicate that, in spermatozoa and possibly also in spermatogenic cells, shuttle systems that oxidize cytosolic NADH and transfer the reducing equivalents to the mitochondrial electron-transport chain operate at a rather low rate.

Rat spermatozoa may oxidize cytosolic NADH via the malate-aspartate shuttle system (Brooks, 1978). Furthermore, it has been suggested that branched-chain $\alpha$-oxo acids and isoenzyme LDH$\mathrm{C}_{+}$participate in a male-germ-cell-specific shuttle system for the transport of reducing equivalents into the mitochondrial matrix (Blanco et al., 1976; Montamat et al., 1978; Burgos et al., 1982). The latter shuttle system would be dependent on the presence of isoenzyme $\mathrm{LDH}-\mathrm{C}_{4}$ in the mitochondrial matrix and the endogenous production of branched-chain $\alpha$-oxo acids (Montamat et al., 1978). The conclusion that the enzyme branchedchain amino acid aminotransferase is present in mouse spermatogenic cells, however, was based on the isolation of subcellular fractions from total testicular tissue (Montamat et al., 1978). Isolated rat spermatocytes and spermatids neither contain a significant activity of the aminotransferase (Grootegoed et al., 1983) nor produce a detectable amount of 4-methyl-2-oxovalerate from leucine, as described in the present paper. Furthermore, the notion that isoenzyme $\mathrm{LDH}-\mathrm{C}_{4}$ could be present in the mitochondrial matrix of spermatogenic cells is not generally accepted (Goldberg, 1977). Most, if not all, of the isoenzyme LDH-C 4 is in the cytosol (Goldberg, 1977). The present results seem to reflect the NADH-dependent conversion of exogenous 4-methyl-2-oxovalerate into 2-hydroxy-4methylvalerate in the cytosol of rat spermatocytes and spermatids, and the release of 2-hydroxy-4methylvalerate by the spermatogenic cells.

\section{References}

Beaumont, H. M. (1960) Int. J. Radiat. Biol. 2, 247-256

Blanco, A., Burgos, C., Gerez de Burgos, N. M. \& Montamat, E. E. (1976) Biochem. J. 153, 165-172

Brooks, D. E. (1978) Biochem. J. 174, 741-752

Brooks, D. E. \& Mann, T. (1972) Biochem. J. 129, 10231034

Burgos, C., Coronel, C. E., Gerez de Burgos, N. M., Rovai, L. E. \& Blanco, A. (1982) Biochem. J. 208, 413417

Chang, S.-M. T., Lee, C.-Y. \& Li, S. S.-L. (1980) Int. J. Biochem. 11, 1-6

Eagle, H. (1959) Science 130, 432-437

Fritz, I. B. (1978) Biochem. Actions Horm. 5, 249-281

Goldberg, E. (1977) in Isozlmes: Current Topics in Biological and Medical Research (Rattazzi, M. C., Scandalios, J. G. \& Whitt, G. S., eds.), vol. 1, pp. 79124, Alan R. Liss, New York

Grootegoed, J. A., Kruger-Sewnarain, B. C., Jutte, N. H. P. M., Rommerts, F. F. G. \& Van der Molen, H. J. (1982) Gamete Res. 5, 303-315

Grootegoed, J. A., Jutte, N. H. P. M., Jansen, R. \& Van der Molen, H. J. (1983) Horm. Cell Regul. 7, 299-316

Grootegoed, J. A., Jansen, R. \& Van der Molen, H. J. (1984) Biochim. Biophys. Acta 767, 248-256

Jutte, N. H. P. M., Grootegoed, J. A., Rommerts, F. F. G. \& Van der Molen, H. J. (1981) J. Reprod. Fertil. 62, 399-405

Jutte, N. H. P. M., Jansen, R., Grootegoed, J. A., Rommerts, F. F. G., Clausen, O. P. F. \& Van der Molen, H. J. (1982) J. Reprod. Fertil. 65, 431-438

Jutte, N. H. P. M., Jansen, R., Grootegoed, J. A., Rommerts, F. F. G. \& Van der Molen, H. J. (1983) J. Reprod. Fertil. 68, 219-226

Lowry, O. H., Rosebrough, N. J., Farr, A. L. \& Randall, R. J. (1951) J. Biol. Chem. 193, 265-275

Meistrich, M. L., Trostle, P. K., Frapart, M.\& Erickson, R. P. (1977) Der. Biol. 60, 428-441

Montamat, E. E., Moreno, J. \& Blanco, A. (1978) J. Reprod. Fertil. 53, 117-123

Robinson, R. \& Fritz, I. B. (1981) Biol. Reprod. 24, 1032 1041

Shinnick, F. L. \& Harper, A. E. (1976) Biochim. Biophys. Acta 437, 477-486

Tanaka, K., Hine, D. G., West-Dull, A. \& Lynn, T. B. (1980) Clin. Chem. 26, 1839-1846 